\title{
ЩОДО РЕФОРМУВАННЯ СУДОВОЇ СИСТЕМИ В УКРАЇНІ
}

Гуйван П. Д.

Стаття присвячена дослідженню актуального питання щодо підставності та спрямованості реформування національної системи судівництва, включаючи створення оновленого органу судового врядування. Визначено правові підстави такого рішення - серйозні та систематичні порушення чинного українського законодавства під час проведення добору до складу Верховного Суду. В статmі також досліджені рішення судів, які, на переконання автора, не спрямовані на досягнення більшої відкритості у діях органу публічної влади. Таке правозастосування суперечить $\mathrm{cm}$. 10 Конвенціі про захист прав людини і основоположних свобод.

Ключові слова: прозорість діяльності, публічна інформація, справедливий суд.

Статья посвящена исследованию актуального вопроса направленности реформирования национальной системы судопроизводства, включая создание обновленного органа судебного управления. Определены правовые основания такого решения - серьезные и систематические нарушения действующего украинского законодательства при проведении отбора в состав Верховного Суда. В статье также исследованы решения судов, которые, по мнению автора, не направлены на достижение большей открытости в действиях органа публичной власти. Такое правоприменение противоречит $\mathrm{cm}$. 10 Конвенции о защите прав человека и основных свобод.

Ключевые слова: прозрачность деятельности, публичная информация, справедливый суд.

This scholarly article is dedicated to exploring the urgent issue of the subject matter and purpose of reforming the national judiciary, including the establishment of an updated judicial administration body. The paper assesses the reasons for the unprecedented decision by the Ukrainian Parliament to dissolve the High Qualifications Commission of Judges without giving it the right to conduct a transitional period and without the possibility for former members of the Commission to apply for this position. The legal grounds for such a decision are determined - serious and systematic violations of the current Ukrainian legislation during selection in the Supreme Court. One of the main abuses of the legislator is recognized frauds with information about the results of the competition. The selection, contrary to the law, was conducted in a closed and non-transparent manner, which led to numerous abuses. Therefore, the study examines the factors that influence the organization of a fair trial in terms of the uniqueness and consistency of personnel decisions, openness and honesty of selection procedures, etc. Specific examples have analyzed the unreasonable concealment by the judicial authority of information about the selection of judges, misrepresentation, ignoring requests and other abuses of the subject of authority in order to conceal from the public information of public interest. The article also examines the decisions of the courts, which, in the author's opinion, are aimed not at achieving greater openness in the actions of the public authority regarding public awareness of their work, but at the unlawful evasion of the duties provided by law. Such enforcement is contrary to the legislation of Ukraine on access to public information and Art. 10 of the Convention for the Protection of Human Rights

Гуйван П. Д., 2019 and Fundamental Freedoms. Moreover, the author is convinced that the position of the Supreme Court, according to which the public information manager should make it available to all interested parties only when the law so requires, effectively prevents such information from being freely accessible and creates serious obstacles to the activities of the newly created Commission openness of her work.

Key words: transparency of activity, public information, fair trial.

Постановка проблеми та ії актуальність. Нещодавно набув чинності Закон України «Про внесення змін до закону України «Про судоустрій і статус суддів» та деяких законів України щодо діяльності органів суддівського врядування» (закон № 1008). Цим актом, зокрема, передбачено проведення нового оцінювання суддів Верховного Суду в межах конкурсу, що буде проводитися на посади у кількості, встановленій Законом. Крім того, за правилами вказаного нормативно-правового документу від дня вступу його в силу припинили свою діяльність члени колегіального органу, покликаного здійснювати формування національного суддівського корпусу та контроль за його роботою, Вищої кваліфікаційної комісії суддів (ВККС). Головною причиною такого кардинального кроку вказується наявність численних порушень та істотних зловживань з боку минулого складу Комісії під час проведення недавнього добору на посади суддів ВС. Повністю новий склад мусить бути сформований спеціальною комісією, створеною Вищою радою правосуддя за участі міжнародних експертів.

Конституція України, закріплюючи основи правової, демократичної та соціальної держави, визначає, що права і свободи людини та їх гарантії визначають зміст і спрямованість діяльності держави. Серед основоположних прав, гарантованих кожній особі, $\epsilon$ право вільно збирати, зберігати, використовувати і поширювати інформацію усно, письмово або в інший спосіб - на свій вибір (ст. 34). А стаття 32 Конституції передбачає, що кожний громадянин має право знайомитися в органах державної влади, органах місцевого самоврядування, установах і організаціях з відомостями про себе, які не $\epsilon$ державною або іншою захищеною законом таємницею. Важливою гарантією цього конституційного принципу $\epsilon$ право кожного на оскарження в суді рішень, дій чи бездіяльності органів державної влади, органів місцевого самоврядування, посадових і службових осіб (ст. 55 Конституції України). Разом з тим, крім загального декларування основних демократичних ідей права на доступ до інформації, українська правова система мусить врегулювати конкретні відносини в окремих галузях матеріальних взаємодій, чого поки що, на жаль, не спостерігається. Цей аспект діяльності законодавця обов' язково має реалізовуватися на основі ретельного дослідження та застосування міжнародного правового досвіду. 
Аналіз останніх досліджень і публікацій. Коментовану проблематику в правовій літературі висвітлювали такі науковці, як С. Василенко, В. Порада, Н. Тимченко, В. Паліюк, С. Головатий, П. Рабінович, Д. Супрун, Ю. Тодика, Б. Кормич, В. Мармазов, Б. Тоцький, О. Романюк, О. Логінов, А. Марущак, В. Паламарчук та інші. Разом з тим залишаються недостатньо вивченими чинники, що впливають на організацію справедливого судочинства в частині однозначності та несуперечливості кадрових рішень, відкритості та чесності процедур добору тощо. Не отримали достатньої уваги такі питання, як необґрунтовані приховування органом судового врядування інформації про проведення добору суддів, перекручування фактів, ігнорування запитів та інші зловживання суб'єкта владних повноважень з метою приховати від суспільства відомості, які становлять публічний інтерес.

Метою статті $\epsilon$ вивчення фактичного правозастосовного матеріалу щодо проведення конкурсу на посади суддів в Україні в частині обмежень інформаційного доступу, зокрема в сфері реформування національної системи судівництва.

Виклад основного матеріалу. Усі серйозні дослідники проведеного у 2016-2019 роках конкурсу до Верховного Суду, серед яких поважні громадські організації, науковці, журналісти, правники, практично одноголосно вказували на суттєві недоліки у діяльності ВККС. Йшлося про вражаючу закритість конкурсу, непрозорість даних про хід оцінювання, махінації Комісії з проведенням тестувань, виставлянням балів кандидатам та інші суттєві правопорушення [1]. Проведений аналіз підтверджує всі ті звинувачення, котрі лунали з боку громадськості весь цей час. Походження виставлених балів за рахунок закритості процесу стало незрозумілим ні суспільству, ні самим кандидатам. Зазначене приховування своєї діяльності, нереагування на заклики представників суспільства забезпечити прозорість всього процесу оцінювання, як і задумувалося комісією, дозволило тривалий час приховувати маніпулятивні вчинки із оцінюванням кандидатів. I так тривало б і надалі, якби не зміни в державі, адже цілком очевидно, що ВККС діяла у подібний незаконний спосіб на замовлення попередньої влади.

Звернімося передусім до законодавчих правил. Закон «Про судоустрій і статус суддів» вказує, що кваліфікаційне оцінювання проводиться прозоро та публічно, у присутності судді (кандидата на посаду судді), який оцінюється, та будь-яких заінтересованих осіб (ч. 4 ст. 84). При цьому Вища кваліфікаційна комісія суддів України зобов'язана забезпечити прозорість іспиту, на кожному етапі та під час оцінювання результатів можуть бути присутніми будь-які заінтересовані особи (ч. 1-2 ст. 85). Таким чином, основний акт, що діє у цій сфері, вимагає від ВККС максимальної прозорості проведення конкурсу, який відбувається за процедурою кваліфікаційного оцінювання. В той же час Комісія усіляко намагалася утаємничити не лише здійснення процедури добору, а й активно приховувала його результати. Як доведено фахівцями, ці речі робилися умисно: досягався результат, коли підсумки конкурсу ніяк не узгоджуються з висхідними даними більшості кандидатів, що містяться у їхніх досьє та обговорювалися під час співбесід, але дані факти були закриті для суспільства.
Попри те, що громадськість неодноразово закликала ВККС опублікувати практичні завдання для кандидатів до Верховного Суду, їхні роботи, а також оцінки членів Комісії за результатами конкурсу [2], прохання забезпечити прозорість оцінювання практичних завдань, були проігноровані Комісією. Між тим, подібні вимоги щодо опублікування робіт та оцінок були зумовлені не лише приписами Закону про відкритість конкурсу, а зокрема тим, що аналіз результатів демонстрував видимі відхилення від кривої нормального розподілу результатів або, іншими словами, свідчив про високу ймовірність втручання у визначення результатів [3]. Таким чином, важко не погодитися з висновками шанованих громадських організацій: «Під час конкурсу до Верховного Суду вимога забезпечити прозорість оцінювання практичних завдань була проігнорована Комісією. Проблема залишилася актуальною і під час кваліфікаційного оцінювання. Так, ВККС засекретила виконані суддями практичні завдання, методологію їх оцінювання, оцінки кожного члена Комісії, який перевіряв роботи. Хоча методологія оцінювання містить детальний розподіл балів, які суддя може отримати за кожним із критеріїв та підкритеріїв оцінювання, ВККС оприлюднює лише фінальний бал, який отримує суддя. Такий підхід ВККС унеможливлює будь-який зовнішній контроль за відсутністю зловживань на етапі перевірки практичних завдань. Ураховуючи наявність математично обґрунтованих сумнівів щодо наявності втручання в оцінювання результатів практичних завдань, Комісії правильно було б потурбуватися про розвіяння будь-яких сумнівів щодо достовірності результатів оцінювання [4]. Як видно, ці та подібні зауваження і заклики фахівців залишилися недосяжними для комісії, «караван іде». Ось тільки куди він заведе, які будуть наслідки для караванників, покаже час і славнозвісна політична воля, чи, вірніше, - іiі наявність.

3 урахуванням викладеного наразі слід говорити не лише про звільнення нинішніх чиновників зазначеного органу, як то передбачено законом № 1008. Якщо країна хоче не тільки змінитися, а й очиститися від того бруду та беззаконня, який у коментованій царині уособлюється саме ВККС, необхідно обов'язково провести спеціальне розслідування діяльності цього органу, встановити особистий «внесок» кожного з фігурантів у зловживання, злочинні маніпуляції та правопорушення, що коштували нашому народові так дорого, і притягти кожного з них до адекватної відповідальності. Тільки у такому разі можна буде сказати, що реформа судівництва відбулася, а процес корумпованого та несправедливого добору суддів пішов у минуле, і це має незворотний ефект.

3 огляду на відверту незаконність діяння ВККС у інформаційній сфері та поворот суспільної думки щодо оцінювання таких вчинків окремими особами, які всупереч закону про доступ до публічної інформації отримали відмову у доступі до відомостей, що мають суспільне значення, було подано позови до Верховного Суду про визнання дій незаконними та про зобов'язання Комісії надати відповідну інформацію. Згідно з ч. 1 ст. 2 Кодексу адміністративного судочинства України завданням адміністративного судочинства $\epsilon$ захист прав, свобод та інтересів фізичних осіб, прав та інтересів юридичних осіб у сфері публічно-правових відносин від порушень з боку органів державної влади, 
органів місцевого самоврядування, їхніх посадових і службових осіб, інших суб'єктів під час здійснення ними владних управлінських функцій на основі законодавства, зокрема на виконання делегованих повноважень шляхом справедливого, неупередженого та своєчасного розгляду адміністративних справ.

Показовим $\epsilon$ розгляд подібної справи № 9901/293/19 [5]. Слід зазначити, що, попри пред’явлення позову у липні 2019 року, остаточний розгляд справи відбувався 10 грудня 2019 року, тобто після того, як за Законом Вища кваліфікаційна комісія суддів в особі їі членів припинила свою діяльність у попередньому складі. Наступний склад цього органу буде сформовано за результатами проведеного конкурсного добору, який лише стартував. Отже, на цей час такого органу, який зветься ВККСУ, не існує, жодної посадової особи, що є членом цієї Комісії, немає фізично. При цьому показово, що Верховна Рада - єдиний законодавчий орган країни, переважною більшістю голосів прийняла рішення, яким негайно припинила повноваження ВККС, не надавши їй звичайного за подібних обставин повноваження - здійснення розпорядчих функцій на перехідний період до обрання нового складу. Навіть більше, жодному з членів попереднього складу ВККСУ не дозволено за приписом Закону балотуватися до нового складу Комісії, навіть тим, які були туди обрані щойно перед припиненням повноважень. Такий безпрецедентний крок, пов'язаний з абсолютною недовірою членам попереднього складу Комісії, свідчить лише про одне: склад ВККСУ розформовано в зв'язку з незаконними, корумпованими та непрофесійними діями цього органу. Про це чітко зазначено у пояснювальній записці до проекту закону, а також стосовно протиправності дій Комісії висловився 09 жовтня 2019 року в інтерв'ю виданню Цензор.НЕТ представник Президента України в Конституційному Суді України Федір Веніславський. Таким чином, бувший склад себе повністю дискредитував, тож абсолютно логічно і безсумнівно, що нові члени ВККСУ, будучи обраними, намагатимуться виправити помилки своїх попередників і не будуть їх повторювати, у тому числі і щодо тих питань, які $є$ предметом чинних судових розглядів. Попри те, що Велика Палата Верховного Суду, власне, не мала права розглядати спір за фізичної відсутності в природі самого учасника спору - ВККС, вона, тим не менше, розглянула справу. При цьому як аргумент у суді оцінювалася позиція вже розформованого органу, причому значною мірою в зв'язку із незаконністю дій саме в тій площині, яка була предметом розгляду. Між тим, вищий судовий орган України підтримав позицію відповідача у бувшому складі, згідно з якою Комісія не повинна надавати інформацію учаснику конкурсу. Власне, незважаючи на констатацію Законом незаконності дій ВКкСУ і розпуск іï Верховний Суд фактично вчиняє спробу реабілітації цієї інституції, зазначаючи, що вона діяла законно, відмовляючи запитувачу в доступі до публічної інформації.

Чим же аргументує суд відмову в доступі позивача до інформації про рівень своїх оцінок за різними кваліфікаційними показниками, отриманих під час його участі в конкурсі на посаду судді одного із вищих судів України? Верховний Суд вказує, що «рейтинг кандидатів на зайняття вакантних посад за окремими критеріями (показниками) Комісією не визначається, а тому неможливо надати інформацію про рівень рейтингової оцінки кандидата на посаду судді ними». Але така позиція якраз знаходиться у суперечності з положеннями українського закону. Навпаки, законодавство вказує, що кваліфікаційне оцінювання кандидатів проводиться окремо за кожною з 10 позицій, визначених у «Положенні про порядок та методологію кваліфікаційного оцінювання, показники відповідності критеріям кваліфікаційного оцінювання та засоби їх встановлення» (Положення). За кожною з позицій законодавством визначені окремі, лише даному критерію притаманні показники відповідності кандидата; за кожним критерієм виставляється своя оцінка в межах, визначених нормативно; за законодавчим правилом відбувається сумування вказаних оцінок і отримання у такий спосіб арифметичного значення остаточної суми показників рейтингу.

Якщо цього не зробити, як то робив попередній склад ВККСУ та зараз робить Верховний Суд, фізично неможливо встановити підсумкову загальну рейтингову оцінку. Давайте проведемо нескладне дослідження в межах предмету цієї справи, яке, на жаль, покаже неспроможність суддів Великої Палати вести аналітичну роботу, бо вони перебувають у тенетах «переконливості» аргументів відповідача без їхнього хоча б побічного дослідження. Уявімо собі, всупереч закону, що суд має рацію, і в процесі проведення конкурсу Комісія може взагалі не оцінювати рівень окремих рейтингових показників кандидатів (нагадаю, що законодавство містить критеріальні оцінки різних рейтингових позицій в розмірі від 10 до 100 балів). Отже, припустимо, що ці оцінки $є$ невідомими, бо окремо не проводилося відповідне оцінювання. Тоді просто дурницею виглядає можливість визначення сумарного результату за відсутності хоча б одного з доданків (хоча, як стверджує відповідач, у нього немає жодного доданку). Звісно, це питання поставало перед судом. Але цей суд у стилі усталеного судочинства за участі органу, що його призначив, уникнув взагалі його розгляду. Але, хочемо ми того, чи ні, необхідно дати відповідь на питання, що прямо стосується даного позову: «яким чином ВККСУ могла визначити рейтингову оцінку за загальний результат конкурсу, якщо вона не здійснювала оцінювання окремих рейтингових позицій, які за нормативним приписом $\epsilon$ складовими елементами загальної оцінки?» Розумної, зрозумілої відповіді на нього немає.

Та закон все ж надає відповідь на це питання, але не такого змісту, який використовує суд, а якраз навпаки. У тій же ст. 83 ЗУ «Про судоустрій і статус суддів» вказується, що Порядок та методологія кваліфікаційного оцінювання, показники відповідності критеріям кваліфікаційного оцінювання та засоби ї встановлення затверджуються ВККС. Усім добре відомо, що відповідний документ затверджений Комісією, він використовується уже не вперше під час проведення подібних конкурсів. За відсутності якогось іншого акту цей делегований Законом документ $\epsilon є д$ ним та визначальним у досліджуваній сфері. Якщо не полінуватися та ретельно передивитися до вказаного нормативного акту, неважко помітити, що за приписом п. 2 глави 6 «показники відповідності судді (кандидата на посаду судді) критеріям кваліфікаційного оцінювання досліджуються окремо один від одного та у сукупності».

Згідно з правилом пункту 5 глави 6 Положення встановлений перелік критеріїв оцінювання під час прове- 
дення конкурсу. В цьому акті визначено також ознаки відповідності кандидата кожному критерію, вказується максимальна сума балів за кожним критерієм. Усі ці показники досліджуються як окремий елемент загального вивчення рівня особи з урахуванням перелічених вище чинників і оцінюється певною сумою балів, яка $\epsilon$ складовою загального балу за результатами кваліфікаційного оцінювання. Інакше просто бути не може. Бо якщо спитати Комісію та суддів Верховного Суду, хто i в якому порядку має виставляти бали та оцінювати відповідність кандидатів за кожним критерієм, як то передбачено законодавством, отримаємо традиційне, але значуще мовчання.

Отже, за законом ВККСУ зобов'язана, як того вимагає законодавство, провести кваліфікаційне оцінювання кандидата за даними, вказаними у п. 6 глави 2 розділу II Положення, і мотивована оцінити його в межах встановлених за кожним критерієм балів. Саме на такий порядок дій під час проведення конкурсу вказує нормативний акт, і саме це, попри законодавчі приписи, намагається ігнорувати відповідач та підтримує суд. При цьому Комісія вперто вказує, що жодних оцінювань за окремими критеріями не повинно проводитися та не проводилося. Але, насправді, без визначення хоча б одного з критеріїв встановити рівень загальної оцінки кандидата фізично неможливо. Це не під силу навіть Лейбніцу чи Ньютону!! Взагалі будь-які математичні операції з рейтинговими показниками конкретних кандидатів за окремими кваліфікаційними показниками просто унеможливлюються, враховуючи те, що, як стверджує ВККСУ, вона не визначала окремо ніяких оцінок за окремими критеріями, встановленими законодавчо. То, схоже, становить протиправну мету Комісії, підтриману судом, - унеможливити перевірку законності, відкритості та обґрунтованості результатів кваліфікаційного оцінювання. Як бачимо, непрозора, закрита та неправильна за суттю система оцінки кандидатів не завадила відповідачеві, попри математичні та фізичні закони та здоровий глузд, вивести цифри фінального рейтингового оцінювання всіх кандидатів.

На обґрунтування свого одіозного рішення від 10 грудня 2019 року у справі № 9901/293/19 Велика Палата вказує, що запитувана позивачем інформація не повинна йому надаватися, бо Закон не вказує на обов'язок розпорядника публічних відомостей - ВККС, надавати запитувачу саме дані про його рейтингову оцінку за окремими критеріями, визначеними законом. Суд, зокрема, вказує: «ані Закон № 1402-VIII, ані Положення № 143/зп-16 обов' язку щодо окремого фіксування ВККС балів щодо оцінювання кандидатів на посаду судді за показниками, визначеними у п. 5 глави 6 цього Положення, не передбачають». Це твердження, хоч з якого боку його не розглядай, виглядає незграбним i, насправді, робить ведмежу послугу відповідачеві. Адже і Закон № 1402-VIII, і Положення № 143/зп-16 взагалі не кажуть про порядок фіксації будь-яких результатів кваліфікаційного оцінювання. Відтак, за судовою логікою, орган публічної влади, на якого поширюється закон «Про доступ до публічної інформації», може взагалі не фіксувати та не зберігати якісь дані про кваліфікаційне оцінювання кандидатів у суді. Такий підхід вищого судового органу взагалі нівелює приписи чинного національного законодавства, переводячи відносини в площину, де жодний розпорядник публічної інформації ніколи не буде зобов'язаний надавати вільний доступ до неї. Фактично, ВС поховав принципи вільного отримання інформації, передбачені у ст. $34 \mathrm{Koн-}$ ституції та ст. 10 Європейської конвенції про захист прав людини і основоположних свобод. Адже вимога щодо надання публічної інформації запитувачу лише тоді, коли саме ці відомості передбачені в законі, зводить нанівець дієвість та ефективність Закону України «Про доступ до публічної інформації». Бо, як неважко помітити, в жодному законі немає переліку даних, які можуть бути запитані і надані розпорядником, у тому числі ВККС. Якщо пристати на логіку Верховного Суду, отримаємо результат, коли будь-який орган влади, у тому числі ВККС, вправі відмовити особі у зверненні за публічною інформацією, оскільки у якомусь законі не передбачено, що саме такі відомості можуть надаватися запитувачу.

На щастя, подібний підхід відверто не узгоджується з ЗУ «Про доступ до публічної інформації» та міжнародною правозахисною практикою, вираженою у прецедентних рішеннях ЄСПЛ, які $\epsilon$ джерелом національного права. Дійсно, за ст. 1 зазначеного Закону публічна інформація - це відображена та задокументована будьякими засобами та на будь-яких носіях інформація, що була отримана або створена в процесі виконання суб'єктами владних повноважень своїх обов'язків, передбачених чинним законодавством, або яка знаходиться у володінні суб'єктів владних повноважень, інших розпорядників публічної інформації, визначених цим Законом. Цілком очевидно, що запитувана інформація щодо конкретних оцінок за окремими рейтинговими показниками перебуває або повинна перебувати в розпорядженні відповідача, оскільки, як вже вказувалось, він без цих даних просто на зміг би обрахувати остаточні результати. Тож Комісія мусила надати запитувачу відповідну інформацію.

3 проведеного дослідження можна зробити такі висновки. Як бачимо, неправовий консенсус між судом і органом, який цей суд, власне, призначив, $є$ поки що звичним негативним явищем. I це ще раз підтверджує необхідність реформ судочинства та судового врядування, які наразі проводяться згідно з законом № 1008. Але в такому разі виникає ще одне, дуже не пересічне питання. Уявімо, що найближчим часом буде закінчено оголошений законом новий добір на посади членів ВККСУ, і цей орган почне свою роботу, яка на тривалий час була припинена. За самим сенсом закону і з огляду на загальновизнану неправомірну інформаційну політику попередників Комісія не повинна продовжувати нехтувати інформаційними правами громадян. Звісно, нові люди прагнутимуть побудувати свою політику та відносини з громадськістю на засадах відкритості та прозорості, тобто саме так, як вимагає Закон України «Про судоустрій і статус суддів». Але цього він апріорі зробити не зможе. Бо ще до створення нової ВККС Верховний Суд встановив обмеження у доступі до публічної інформації, визнавши, що Комісії іï надавати запитувачам не потрібно. Що ж ми отримаємо в результаті. А ось що. Нова комісія або буде таким же закритим і непрозорим, а відтак схильним до маніпуляцій і незаконних оборудок органом, тож їі чекає доля попередників, або ж вона відкине рішення Верховного Суду про заборону доступу осіб до публічної інформації та діятиме винятково відповідно до приписів закону. 


\section{Література}

1. Значну частину інформації про конкурс до Bерховного суду приховують журналісти. iPress.ua. URL: https://ipress.ua/news/znachnu_chastynu_informatsii_pro_ konkurs_do_verhovnogo_sudu_pryhovuyut_zhurnalisty_ 208676.html.

2. РПР вимагає від ВККС оприлюднити роботи та оцінки кандидатів на посади суддів Верховного Суду. URL: https://rpr.org.ua/news/rpr-vymahaje-vid-vkksoprylyudnyty-roboty-ta-otsinky-kandydativ-na-posadysuddiv-verhovnoho-sudu/.

3. Маніпуляції з результатами конкурсу до Верховного Суду: статистичні докази / Блог Михайла Жернакова / URL: https://blogs.pravda.com.ua/authors/ zhernakov/58e4a2e32738e/f.

4. Кваліфікаційне оцінювання суддів 2016-2018: проміжні результати. Аналітичний огляд підготовлено експертами громадських організацій: Центр політико-правових реформ у межах проекту «Посилення ролі громадянського суспільства у забезпеченні демократичних реформ і якості державної влади» за підтримки Європейського Союзу Фундація ДЕЮРЕ у межах програми МАТРА за фінансової підтримки Посольства Королівства Нідерланди ВО «Автомайдан» у межах Програми сприяння громадської активності «Долучайся!», що фінансується Агентством США з міжнародного розвитку (USAID) та здійснюється Pact в Україні URL: https://rpr.org.ua/wp-content/uploads/2019/04/1554 460296qualification_report_full_eu.pdf.

5. Справа № 9901/293/19. Архів Касаційного адміністративного суду Верховного Суду за 2019 рік.

Гуйван П. Д., кандидат юридичних наук, заслужений юрист України, професор Полтавського інституту бізнесу 